Opinion

\section{COVID-19 situation in Nepal}

\author{
Hom Nath Chalise ${ }^{1,2 *}$ \\ ${ }^{1}$ Faculty Member, Department of Public Health, Nobel College Affiliated to Pokhara University, \\ Sinamangal, Kathmandu, Nepal \\ ${ }^{2}$ Vice President, Population Association of Nepal, Kathmandu, Nepal
}

Coronavirus disease 2019 (COVID-19) which first appeared in China spread gradually all over the world within three months [1]. China was the only country mainly affected by Covid-19 until February 2020, but from the beginning of March, the disease started to spread rapidly to South Korea. It reached Italy in the second week of March and the number of cases increased rapidly in Spain and other European countries in the third week of March then the virus crossed the Atlantic and entered into the United States and other countries in the Americas. WHO declared COVID-19 as a pandemic disease on $11^{\text {th }}$ March 2020 [2]. As of $23^{\text {rd }}$ April 2020, there have been 2,645,785 confirmed cases of COVID-19, with 185,121 deaths and 726,827 recoveries [3]. Slowly, Nepal is also into the scene of the COVID-19 affected countries.

Nepal is a landlocked country situated between China and India in South Asia. For some years now many Nepalese students have been going to China for higher education and many Chinese workers are also employed in different Chineseled development projects in Nepal. On the other hand, Nepal shares an open border with India and people can easily cross the border without any legal documents and do not need any work permit to work on either side of the border. Similarly, many Nepalese (more than three million) work different countries all over the world other than India [4], and a large number of students go abroad for higher education as well. It shows that there is a high mobility of Nepalese these days.

Nepal is not free from the pandemic effect of COVID-19. It was on $24^{\text {th }}$ January that Nepal confirmed the first case of the deadly coronavirus in the country identifying the infected person as a Nepali student who had returned from the Chinese city of Wuhan. The 31-year-old man, who was doing his Ph.D. in Wuhan, had returned from the Chinese city on January 5. He had visited a hospital complaining of respiratory problems and was admitted to the hospital on $13^{\text {th }}$ January. Negative results for COVID-19 were given by consecutive follow-up tests on January 29 and 31 [5].

It took more than one month for Nepal to confirm the second case of Covid-19 (23 ${ }^{\text {rd }}$ March) and the victim was a 19-year-old Nepali girl returning from France [6]. In the

\section{More Information}

*Address for Correspondence: Hom Nath Chalise, Vice President, Population Association of Nepal, Kathmandu, Nepal, Tel: +977 9851012622; Email: chalisehkpp@gmail.com

Submitted: 16 April 2020

Approved: 24 April 2020

Published: 27 April 2020

How to cite this article: Chalise HN. COVID-19 situation in Nepal. Arch Psychiatr Ment Health. 2020; 4: 033-034.

DOI: 10.29328/journal.apmh.1001015

Copyright: @ 2020 Chalise HN. This is an open access article distributed under the Creative Commons Attribution License, which permits unrestricted use, distribution, and reproduction in any medium, provided the original work is properly cited.

Keywords: COVID-19; Coronavirus; Nepal-India relation; Nepal

\section{Check for updates}

(9) open access

initial phase, most of the confirmed cases of COVID-19 were imported from other countries. It was in $4^{\text {th }}$ of April, 2020 that Covid-19 was traced among relatives of the victims [6]. This has created fear of COVID-19 in Nepal because of local transmission to relatives and neighbours of victims.

To date (22 $2^{\text {nd }} A$ pril), the total number of confirmed cases of COVID-19 in Nepal are 45 among which 38 cases are active and all of them are in good health [6]. No death has been reported in from COVID-19 so far. Udayapur district of eastern Nepal has 27 COVID-19 cases. It is believed that COVID-19 cases spread in this area through Indian Muslims who entered Nepal for religious gathering. So far, at least 15 Indian nationals have been confirmed as positive COVID-19 victims in this region.

The western part of Nepal is also considered another possible vulnerable area for COVID-19. The India-Nepal border is mostly open and porous, and even at official checkpoints health desks are only equipped with thermometers. Recently thousands of Nepalis have returned to western Nepal without screening from Indian states of Maharastra, Delhi and Bihar, which are the hardest-hit COVID-19 states in India. The mountainous districts of western Nepal are considered to be the most vulnerable because every Nepalese family has at least one member working in India, most of whom have now returned due to the lockdown. Two people who returned from India have been confirmed with COVID-19 in this area. Recently, The Nepali government has increased the number of 
Rapid Diagnostic Test (RDT) tests in all the affected areas, and thus the number of cases may increase alongside the number of tests. However, some experts doubt about the quality of such RDT kits to confirm the COVID-19.

The Nepali government has prioritized awareness-raising activities and prevention activities to control the spread of COVID-19 cases [6]. Nepal has canceled the much-publicized Visit Nepal 2020 program. Land borders with India as well as China are completely sealed off, and all international flights are now suspended. All academic examinations are canceled, and schools and colleges are closed. Quarantine centers and temporary hospitals are being setup across the country. Laboratory facilities are being upgraded and expanded. Hospitals have been setting up ICU units and isolation beds. The SAARC countries have pledged to cooperate with each other in preventing and controlling the disease in the region. A country-wide lockdown came into effect on 24 March and has been extended until $27^{\text {th }}$ April.

Due to geographic and socio-economic relation between India and Nepal, the COVID-19 control policy of Nepal is also to some extent dependent on Indian government activities. At first, most of the infection in India was restricted to the upper-class society where the victims have a direct or indirect connection within the infected counties [7]. But later evidence shows that more than 20,000 people are infected and more than 700 casualties [3]. It shows COVID-19 has affected the middle as well as economically lower-class people. The Indian government enforced a nationwide lockdown on March 24 to control the possible spread of coronavirus, extended until May 3. The long prevalence of this pandemic may create different types of psychological disorders among people staying in the lockdown [8]. Lockdown is also creating chaos and huge difficulties for people in India [7]. Many Nepalese are still believed halted in different parts of India due to lockdown situation. When they return back to Nepal, there is a high possibility that many of them may carry COVID-19 into the country.
Finally, the current situation in Nepal must be regarded through extremely serious lenses. With mass testing, more cases of COVID-19 begin to emerge. As a country with a fragile healthcare system, and not having the necessary infrastructure to cope with an increasing number of infections, the country is not prepared for a pandemic. Further, unless the border between Nepal and India is completely sealed off, the number of COVID-19 cases in Nepal will keep on increasing.

\section{References}

1. Huang C, Wang Y, Li X, Ren L, Zhao J, et al. Clinical features of patients infected with 2019 novel coronavirus in Wuhan, China. Lancet. 2020; 395: 497-506.

PubMed: https://www.ncbi.nlm.nih.gov/pubmed/31986264

2. WHO. WHO announces COVID-19 outbreak a pandemic. 2020. http:// www.euro.who.int/en/health-topics/health-emergencies/coronaviruscovid-19/news/news/2020/3/who-announces-covid-19-outbreak-apandemic

3. Worldometer. 2020. https://www.worldometers.info/coronavirus/?

4. Baruah N, Arjal N. Nepalese Labor Migration - A Status Report. The Asia Foundation. 2018. https://asiafoundation.org/2018/06/06/ nepalese-labor-migration-a-status-report/

5. Bastola A, Sah R, Rodriguez-Morales AJ, Lal BK, Jha R, et al. The first 2019 novel coronavirus case in Nepal Lancet Infect Dis. 2020; 20: 279-280.

PubMed: https://www.ncbi.nlm.nih.gov/pubmed/32057299

6. Health Emergency Operation Center, Health Emergency and Disaster Management Unit (HEDMU), Ministry of Health and Population, Government of Nepal. Heoc.mohp.gov.np. (2020). Resource materials on Novel coronavirus (2019-nCoV) - Health Emergency Operation Center. https://heoc.mohp.gov.np/update-on-novel-coronavirus-2019_ncov/

7. Sharma S1, Sharma M2, Singh G. A chaotic and stressed environment for 2019-nCoV suspected, infected and other people in India: Fear of mass destruction and causality. Asian J Psychiatr. 2020; 51: 102049. PubMed: https://www.ncbi.nlm.nih.gov/pubmed/32278890

8. Gautam R, Sharma M. 2019-nCoV Pandemic: A disruptive and stressful atmosphere for Indian academic fraternity. Brain Behav Immun. 2020; PMID: 32289366.

PubMed: https://www.ncbi.nlm.nih.gov/pmc/articles/PMC7151469/ 